\title{
Developing Institutional Open Educational Resource Repositories in Vietnam: Opportunities and Challenges
}

Vi Truong ${ }^{1}$, Tom Denison ${ }^{1}$, and Christian M. Stracke ${ }^{2}$

${ }^{1}$ Faculty of Information Technology, Monash University, Australia; ${ }^{2}$ Faculty of Educational Sciences, Open University of the Netherlands, Netherlands

\begin{abstract}
The introduction of open educational resources (OER) provides new opportunities for learners worldwide to access high-quality educational materials at the lowest cost. As a developing country, Vietnam is one of the countries that can most benefit from the OER movement. However, the concept of OER in Vietnam remains little known to the public, with few institutional OER repositories (IOER) developed. This study contends that IOER development in Vietnam is complicated and constrained by many contextual difficulties; it was designed to explore the challenges and opportunities. After a literature review, 20 semi-structured interviews were conducted with relevant stakeholders. Building on the findings from the literature, this study found that IOER development in Vietnam is constrained by five categories of challenges: (a) technological and infrastructure matters, (b) economic constraints, (c) sociocultural characteristics, (d) pedagogical concerns, and (e) legal limitations. Many of these challenges are not identified in the literature and provide insights into potential implications and solutions for future IOER in Vietnam and other countries.
\end{abstract}

Keywords: open educational resources, OER, institutional open educational resource repository development, IOER 


\section{Introduction}

The open educational resources movement is a global phenomenon similar to other open movements such as open education, open-source software, and open access (Stracke, 2020). These grassroot initiatives share a common vision: to make our communities and global society better through free and open solutions. The term open education resources (OER) was coined and defined at a UNESCO forum in 2002 (UNESCO, 2002) and refined via declarations (notably, the 2011 Guidelines on Open Educational Resources in Higher Education) (Stracke et al., 2019). Additional impetus was provided by World Congresses in Paris (2012) and Ljubljana (2017), both organised by UNESCO. The Ljubljana OER action plan (UNESCO, 2017) led to the UNESCO Recommendation on OER, adopted by all 193 member states (UNESCO, 2019). Although the establishment of the OER movement, closely connected to UNESCO, represents a top-down approach, the OER movement has subsequently been driven by grassroot initiatives, communities, and individuals. National authorities, such as the Ministries of Education in the Philippines and Slovenia or supra-national ones, such as the European Union, have started to consider OER as a valuable strategy only in recent years (European Commission, 2013; Stracke, 2019).

OER comprise all types of educational resource in a global, national, or institutional repository that are released with an open license, granting free access and the right to adapt and reproduce resources (Truong, 2020). This study investigates the development of institutional OER repositories (IOER), defined as online archives in universities used for collecting, preserving, and disseminating OER. These OER are either the intellectual output of the university or localised resources from elsewhere.

In Vietnam, the concept of OER was introduced almost two decades ago. In 2002, the Fulbright Economics Teaching Program in Vietnam published its teaching and research materials online. Following a visit in 2005 to the United States by the Vietnamese prime minister, who received a copy of Massachusetts Institute of Technology's (MIT) entire OpenCourseWare (OCW) material, the Vietnam OCW program was established, and in December 2007, an official website (http://www.vocw.edu.vn) was launched; in 2008 it was renamed VOER (Vietnam Open Educational Resources). The OER@University Roadshow program was established in 2016 to train university-level librarians and lecturers across Vietnam to use and create OER. International and national conferences on OER have been organised; the most recent being held in Hanoi in October 2019.

Universities and their libraries in Vietnam have been enthusiastic about participating in OER programs offered by the government or other agencies. However, they remain hesitant to create their own IOER, reflected in the lack of operational IOER. It is believed that the development of IOER in Vietnam is complicated and constrained by contextual difficulties, but little research has been published as to why this is. This article reports on exploratory research designed to investigate the challenges and opportunities in promoting and developing IOER in Vietnam.

\section{Literature Review}

A considerable volume of literature about OER published since 2000 suggests that building a highquality, diverse, and sustainable OER repository is challenging and requires preparation and a wellthought-out strategy on the part of decision-makers and implementers (e.g., Coughlan et al., 2019; Friesen, 2009). The literature identifies five main categories of challenges that countries and 
institutions face when embracing the OER movement: (a) technological and infrastructure limitations, (b) economic constraints, (c) sociocultural characteristics, (d) pedagogical concerns, and (e) legal issues.

Numerous studies have reported constraints related to computing and communications infrastructure in less developed or developing countries (Mtebe \& Raisamo, 2014; Ngimwa \& Wilson, 2012; Thumbumrung \& Aroonpiboon, 2018). Some studies (e.g., Dutta, 2016; McGreal, 2017; Mosharraf \& Taghiyareh, 2016) also indicate that the successful harnessing of OER can be affected by economic factors. Developing IOER requires an initial investment in information and communication technologies (ICT) facilities and infrastructure, services, production costs, policy development, training, and marketing campaigns. Sustaining an IOER project may require significant long-term commitment of resources as the repository's quality is dependent on the quality of maintenance, curation, and preservation (Hodgkinson-Williams, 2010; Hu et al., 2015; Thumbumrung \& Aroonpiboon, 2018).

Sociocultural characteristics have been recognised as a major challenge to advocacy of the open movement in general. These include linguistic diversity, cultural sensitivities, and diversity within a country, as well as stakeholders' characteristics, such as their awareness, willingness, and capacity to adopt OER (Hu et al., 2015; McGreal, 2017; Thumbumrung \& Aroonpiboon, 2018). Pedagogical issues related to educational culture may also hinder adoption of OER. National and institutional teaching and learning culture can directly influence stakeholders' incentives to adopt and produce OER (Hodgkinson-Williams, 2010; Mosharraf \& Taghiyareh, 2016; Thumbumrung \& Aroonpiboon, 2018). The evidence further suggests that legal issues, such as incompatibilities between national intellectual property (IP) rights regulations and OER's open licences, the governance of open licences, and dealing with third-party copyright issues, can prove problematic (Dutta, 2016; OECD, 2007; Pena, 2009).

Scholars in Vietnam (e.g., Do, 2013; Do et al., 2019) have reported contextual challenges to the OER movement based on their conceptions or the perspectives of users, such as users' limited capacity in using OER, the prevalent teaching and learning approaches in the country, or problems related to copyright and IP rights. In Vietnam and internationally, there is a scarcity of empirical research relating to the development of IOER from the viewpoint of higher education providers. The primary goal of the current study is to answer the following question from the perspective of higher education providers: What are the opportunities and challenges in developing IOER in Vietnam?

\section{Methods}

Elman et al. (2020) state that researchers consider using an exploratory approach when there is a general lack of knowledge or little information about the research topic. Because of the lack of research into the contextual challenges and opportunities facing IOER development in Vietnam, the current project was designed as exploratory research. To achieve its objectives, this qualitative study was conducted by adopting an interpretive research paradigm with an inductive reasoning approach capable of providing in-depth understanding of the phenomena being investigated from the interviewees' perspectives. Goldkuhl (2012, p. 135) states that a qualitative approach is often associated with the interpretivist paradigm, which can be applied to "social constructs that are complex and always evolving, making them less amendable to precise measurement or numerical interpretation" (Glesne \& Peshkin, 1992, p. 6). Data were collected through interviews with participants who know about or had participated in the OER movement or IOER development in Vietnam. A combination of non-probability 
sampling techniques (purposive sampling and snowball sampling) was used to select interview participants. The main reason for adopting these sampling techniques is the nature of this research, which targets a group of people who are challenging to identify, locate, and recruit (Williamson, 2017). Analyses of relevant policy and strategy documents, where available, were also undertaken.

Ethics approval was obtained on December 3, 2018. Data collection was undertaken in Vietnam in early 2019. 20 participants were interviewed, from two foreign universities, seven public universities, three private universities, and two education-related organisations, all based in Ha Noi, Hai Phong, Ho Chi Minh City, and Can Tho-four of the largest Vietnamese cities by population. Participants included two university administrators (UA), three IOER leaders (OL), five library administrators (LA), two librarians (LS), two faculty administrators (FA), three faculty members (educators) (F), and three OER champions knowledgeable about and committed to the OER movement (C). IOER leaders are those who lead OER repository development projects in their institutions. Each interview took place face-to-face, averaging 70 minutes. The interviews were semi-structured, with an opening question ("What are the challenges and opportunities of developing IOER at your institution and in Vietnam?") followed by more probing questions (e.g., "How do copyright laws affect teachers and students?”; "Why is achieving institutional autonomy important for OER repository development?”).

The collected data were first transcribed verbatim and then analysed using the conventional content analysis approach (Hsieh \& Shannon, 2005). Using NVivo 12, the codes and concepts emerged directly from the data during the coding process. These were then compared with the literature to gain a broader understanding of the context and sorted into meaningful categories and themes based on their nature, relationships, and suggestions that resulted from the comparison.

\section{Findings}

Five categories of challenges for the development of IOER in Vietnam were derived from the data analysis: technological and infrastructure issues, economic constraints, sociocultural characteristics, pedagogical concerns, and legal limitations.

\section{Technological and Infrastructure Matters}

IOER are primarily collections of digital resources requiring digital tools, software, and systems to be used, and so the impact of technological factors must be considered. Access to ICT devices and Internet connectivity in Vietnam is not an issue; however, 14 interviewees raised technology issues such as low bandwidth, obsolete technologies, and limited access to ICT facilities and hosting services. One champion (C2) suggested that smaller universities in remote areas may find these issues especially challenging and that although a university in Vietnam may be able to develop an IOER to serve its students and staff, it would not be able to afford to serve the whole country or the world.

Ideally, the tools used to create, develop, collaborate, deliver, search, and use open learning content would be open-source. Five interviewees commented that some universities had leaders who understood the value of free and open-source software (FOSS) and had recently implemented opensource tools on their campuses (e.g., Thang Long University and Hai Phong Private University). Most, however, thought that it would be challenging to replace commercial software with FOSS in Vietnam: 
users' apathy towards FOSS is a critical obstacle prevailing against the general benefits of following open principles. As a lecturer explained,

In the past, we also installed open-source software operating systems like Ubuntu for the computers in our learning resource centre ... but not anymore. In fact, the Windows operating system has ingrained in everyone's minds, so when we changed [to the new type], users showed less interest. (F2)

This is potentially a critical issue affecting sustainability, because although the use of FOSS typically requires an initial investment and a reliable arrangement for ongoing maintenance, the costs are generally significantly less than for commercial software and systems and, in particular, annual licence fees.

All interviewees considered university libraries to be best placed to implement IOER within higher education organisations (HEOs). However, to use FOSS, libraries need qualified staff to customise the software to meet their needs and the appropriate authority, funding, and support to do so. Currently, very few libraries are in this situation. As one IOER leader commented,

Developing IOER depends on the policy, economic and technical conditions of each university and country, but in Vietnam, it is especially difficult ... . If we want to make it technically open, we need a comprehensive policy from the university heads. (OL2)

Corroborating previous research, this study found that technological factors have a strong influence on IOER development in Vietnam. Shortcomings relating to the existence, availability, and development of technology need to be addressed to facilitate the development and adoption of the infrastructure needed to support IOER projects. This will take time, money, and significant effort.

\section{Economic Constraints}

The lack of funding for IOER development projects was identified as a critical obstacle by seven interviewees, with funding required for improvements to ICT infrastructure, software and hardware maintenance, staff costs, training, and marketing. Such costs need to be provided for in university budgets and underpinned by appropriate policies and procedures. The director of a university library (OL3) was discouraged by the heavy cost pressures that libraries have recently been under, especially for commercial software licensing and scholarly resources subscriptions.

A library administrator commented, "We need to consider the sustainability aspect, like the annual maintenance fee, who will invest money to do that? ... The creation [of IOER] may not be hard but maintaining it is extremely difficult" (LA1). Indeed, apart from initial financial investment to implement the IOER project, the university needs to secure funding to sustain it.

Participants suggested that the type of education establishment influences the IOER development project. Universities in Vietnam, especially public universities, are overseen by the government and its agencies and have less autonomy than other types of educational establishments. Approximately $70 \%$ of HEOs are publicly funded and must follow state budget laws when planning and carrying out their activities. Financial issues can thus present a significant barrier to projects such as IOER development. This situation may be changing, as many public universities are currently transitioning from the old system of state subsidies to autonomy based on self-financing mechanisms, a move aimed at improving 
the quality of tertiary education. As of 2020, the government has given some key public universities in Vietnam autonomy in areas including the right of self-government in developing policies, designing curriculums, managing budgets, calling for funding, and recruiting personnel. Eleven interviewees suggested that achieving autonomy opens up potential opportunities for public universities to develop IOER in the future. This is seen as an extremely important facilitating factor for the OER movement in Vietnam in general.

The findings suggest that a lack of funding is a principal reason why many university and library administrators are apathetic towards the OER movement in Vietnam.

\section{Sociocultural Characteristics}

Interviewees raised many sociocultural issues they considered problematic, including a shortage of policy from government and university leaders regarding OER and IOER use and development, HEO communities and their attributes such as awareness about OER, attitudes to copyright and copyright enforcement, technological and information literacy, and English proficiency.

The Vietnamese government leads the country through the legal system, policies, and guidelines, playing a vital role in most of the activities of Vietnam's HEOs. Despite some early enthusiasm about OER, there has been a lack of policy development, and little has been done towards creating a supportive framework for OER on the part of government. This was considered a major obstacle by 15 interviewees. One participant commented:

In my opinion, the most important thing is the government's policy on this [OER and IOER]. So far, Vietnam does not have any policy for implementing OER initiatives. ... There have been people in many conferences to speak up on this issue, but the government still has no specific policy. (OL2)

This lack of OER policies means no official recognition, guidelines, support, or rewards exist for creating OER and developing IOER, leading to the apathy of universities, lecturers, and students towards the OER movement.

Limited awareness of OER and a lack of understanding by stakeholders in HEOs of OER's potential were most frequently raised as serious challenges. Fourteen interviewees argued that stakeholders' indifference to the OER movement was primarily due to insufficient appreciation of OER and their educational potential. One informant commented, "OER can only exist and thrive when there is a large number of users; unfortunately, users in Vietnam have not yet recognised those benefits" (OL3). Another explained that the problems their university has been facing also include users' lack of awareness and knowledge of OER: "Even if they know about OER, they do not know where and how to find them for their use" (OL1). Seven interviewees suggested that many Vietnamese lecturers have a mindset that leads them to underestimate the quality or value of OER, as it is free, and they equate free with valueless: "To users, OER means free of charge. In Vietnam, people understand that free stuff is worthless; you get what you pay for!" (OL3).

Attitudes towards copyright are also problematic. Users in Vietnam have a limited understanding of copyright law and what it means for access to various materials. Many believe that everything available on the Internet is publicly owned and can be freely used without crediting the author. Lack of copyright knowledge, perhaps combined with limited information literacy, can result in other issues: for example, 
an IOER leader was surprised to find that some outside users were paying for access to OER materials from a third party when they were freely available on the library website (OL1). As many potential users cannot distinguish between the different copyright statuses of materials, they see little benefit in OER and so lack the motivation to develop and use OER.

Additional challenges relate to the skill levels of OER users and producers in areas such as digital and information literacy and English proficiency. Half of the interviewees suggested that limited digital and information skills are holding users back in terms of harnessing OER efficiently. The basic computer skills of the majority of Vietnamese people are relatively good compared with those of people in other developing countries; however, the capacity for searching, evaluating, localising, and classifying OER remains a hurdle. A library staff member (LS2) observed that many users were confused about evaluating the information sources found on the Internet.

Published OER are expected to be in Vietnamese; however, most existing materials are in English, so proficiency in English is required for their effective use. An IOER leader (OL2) at a foreign-owned university suggested that the process of developing its IOER had been less complicated than it would have been at a key public university, which this participant had previously worked at, due to students at this foreign-owned university having high proficiency in English. A champion added that "foreign language ability of Vietnamese users is quite poor. In the past, MIT provided us thousands of open courses, but our users couldn't use them because they could not understand [those OER]. What a waste!" (C1).

As an educator, a certain level of fluency in English is also required to understand and localise these materials:

Lecturers can use Google translate, but their knowledge of the language is also crucial as they cannot just use Google translate to convert the material's language to Vietnamese and then publish or share it, they need to proofread and revise the content. (OL1)

This particular problem may be changing as Vietnam's government has recently launched Englishtaught advanced training programs at many universities to improve students' English proficiency (LA3). Further, despite numerous potential socioeconomic barriers, in 2018, the minister of Information and Communications submitted a proposal to make Vietnam's second language English, to assist the integration of Vietnam into the global economy. The proposal has received strong support from the community, and the expectation is that in the near future, English will be widely used in Vietnam (C1). Notwithstanding the challenges, the OER movement in Vietnam has the prospect of growing vigorously thanks to proactive champions who are committed to OER activities. Moreover, an increase in the number of university lecturers with overseas training and qualifications is expected to increase awareness of and understanding about the open movement, copyright, and IP rights in Vietnam (OL3; LA4).

\section{Pedagogical Concerns}

Consistent with the literature, this study found that IOER development is impacted by a range of pedagogical issues, including the characteristics of teaching and learning, the existence and popularity of OER in Vietnamese and of developed IOER, and a general lack of recognition of libraries' essential roles. Some of these are closely associated with the economic constraints and sociocultural characteristics identified in previous sections. 
Lecturers in Vietnamese universities have two required tasks: teaching and scientific research. While lecturers invest time and effort in teaching, not all engage in research and publishing, for reasons including lack of time and facilities (stated by three respondents). University lecturers' primary source of income is derived from teaching. Depending on attributes such as seniority, qualifications, degrees, experience, and titles, university lecturers are classified into different categories and have different salary calculation formulas. Their salaries are not high compared with those of people in other careers. Consequently, lecturers often teach additional classes to increase their income, with some even working at private universities as visiting lecturers because the remuneration is higher (C2). The problem was summed up by a university board member, who said that "developing IOER is really difficult in Vietnam because, in my opinion, it is all about our income. We have not yet reached the level where we no longer care about the economic issues" (UA1).

Unwillingness to lose income from copyright materials such as textbooks also prevents some lecturers from creating OER. As a champion noted (C1), although some lecturers are willing to share their work as OER, others want to retain ownership of copyright so as to reprint new editions of textbooks regularly.

This study found that learning and teaching cultures in Vietnam, such as educators' teaching approaches and students' learning habits and practices, also strongly challenge IOER development. Five interviewees submitted that the teacher-centred instruction dominant in Vietnam can limit students' proactivity, curiosity, and exploration. They have less motivation to undertake additional research or seek learning resources, other than those provided by their instructors, to get a satisfactory mark. A participant commented,

Before coming here [a public university], I worked at [A] university library [a foreign-owned university]. I realised the learning and teaching styles of the two universities are very different. Over there, students must go to the library and look for references for their assignments. Students here, on the other hand, only need to learn from the given textbooks. ... They have no independence and desire to learn beyond that. (LA4)

These attitudes may be changing. Recognising the fact that in the information age, the ability to perceive, find, and use information has become a critical skill, a university rector emphasised the importance of encouraging students' curiosity and research:

It's the responsibility of the lecturers in developing the curriculum that requires students to search for and use more learning resources. Our university's training program is designed to reduce the time on classes and give students more time for self-studying. (UA2)

A related issue is lack of familiarity with the culture of sharing IP, for example, by waiving copyright and related rights, which is necessary in an OER environment. A library staff member commented: "In Vietnam, educators are very afraid of 'opening' [showing] the content of their works to others; so persuading them to 'open' their works is also a problem. They are not used to such [sharing] culture" (LS2). It is common practice for both students and lecturers to keep their IP protected and closed to the public. A side effect of this, which also contributes to the issue, is the lack of a comprehensive academic database with which to conduct similarity checks, making it harder to detect plagiarism and IP infringements. As noted by 11 interviewees, the fear of being plagiarised, or being discovered to have 
deliberately plagiarised, is one reason why users in Vietnam are reluctant to "open" their written or published works. One interviewee provided an example:

There was a university library that had two identical dissertations located next to each other on the shelf with the same classification numbers and no one had noticed them. The first librarian catalogued the first book, and after a few years, the second staff member did the second one, so they didn't recognise them. In the end, a reader explored the similarity when reading both of them. (LA3)

There is also a perception that Vietnamese OER are poor quality. The lack of OER localised into Vietnamese language and context and the national VOER's unpopularity are challenging the promotion of the OER movement in Vietnam. When asked about the VOER program, a participant observed,

I know it, but as far as I can see in Vietnam, it's not widely used. When I came to check it out [VOER website], it was unclear and not very easy to use.... Secondly, they did not develop complete textbooks, but created separate pieces. To me, as a user, I doubt their reliability, consistency, and completeness. (OL2)

Such views may, however, depend on the type of stakeholder. Different users have different expectations of educational materials and thus of what should be available as OER. For example, undergraduate students and learners prefer complete resources, such as courses or textbooks, while lecturers are probably interested in reusable learning objects, such as multimedia simulations or case studies. Graduate students will pay more attention to research-supported materials such as open data or academic publications than to lecture slides. Thus, the comment above may not necessarily reflect poor quality but a failure to properly target or cater for the needs of different stakeholders.

Six interviewees reported that currently, OER initiatives in Vietnamese HEOs are mostly ad hoc, with no university having successfully developed a genuine IOER. This situation has led to higher education communities' lack of confidence and willingness to harness OER for teaching and learning practices, or to engage with IOER development activities.

All interviewees regarded university libraries to be best placed to implement and maintain IOER. However, lack of recognition of libraries' essential roles in learning and teaching by other stakeholders was seen as presenting a serious obstacle to IOER development. Such attitudes impact on library staff who, despite acknowledging the benefits of OER, lose motivation due to a lack of authority and incentives, as suggested by two interviewees. These issues appeared to be connected to the type of educational institution and the degree of autonomy of decision-making allowed: private and foreign universities in Vietnam have higher levels of autonomy in comparison with public universities, and thus, they have more flexibility and authority in using and creating OER and developing IOER. The IOER leader from a foreign-owned university explained:

In my university, lecturers have more independence than those from other schools [public universities]. People [OER advocates] need to have a different approach to those lecturers [from public universities] as they need to get permission from their superiors to include OER in the curriculum. (OL2) 
Reflecting the literature, the results of this study show that the pedagogical concerns and practices in HEOs exert a strong influence on the OER movement in Vietnam. The type of education establishment and institutional autonomy are demonstrated to be influential factors for IOER development.

\section{Legal Issues}

Because the concept of OER was only formulated in 2002, it can be expected that issues would arise with the legal systems of numerous countries and that those issues would need to be addressed to create a supportive legal framework. Although Vietnam's IP legislation covers every aspect of the protection of IP following international standards, there are ambiguities relating to copyright ownership of educational resources. For example, a lecturer (F2) commented that as Vietnam has no clear regulations on the legality of open licences, educators hesitate to create and use OER.

The situation is further complicated if the work includes third-party components. Materials created by a member of staff or students at an HEO in the course of their employment or training, for example, research publications and student projects, provide a rich source of educational materials. In such cases, it is not clear whether copyright belongs to the employer (university) or the creator. This lack of clarity in copyright policy and law was noted as an issue by seven participants.

Due to the large number of regulations involved, law enforcement in Vietnam can be complicated. In the education sector, inconsistencies between education law, publishing law, and law on IP rights, together with the low level of penalties and compensation, have resulted in a large number of copyright infringement cases. Consequently, universities are reluctant to act on copyright infringement lest it damage their reputation. An IOER leader revealed an unexpected infringement case in the past (OL3): this person was blamed by another university for giving open access to their university institutional repository so that users could notice the copyright infringements by students at that university.

Consistent with previous studies, this research found that the limitations and inconsistencies of Vietnam's legal system constrain IOER development and also the OER movement in this country.

\section{Discussion}

This research supports the findings reported in the literature: that when developing OER and IOER, HEOs in countries such as Vietnam face a set of challenges in terms of technological and infrastructure matters, economic constraints, sociocultural problems, pedagogical concerns, and legal limitations.

Technology-related factors were identified as influential on the OER movement and especially on the development of IOER in Vietnam, similar to that in other countries described in the literature (e.g., Mtebe \& Raisamo, 2014; Ngimwa \& Wilson, 2012; Torres, 2013). However, the most critical technological problem in Vietnam is not related to access to ICT facilities or Internet connection; rather, it is ensuring the sustainability of the IOER by employing FOSS. Ideally, an open educational resource should be based on open licensing, be open access, and be published in open formats using FOSS (Markoff, 2005). Currently, it would be challenging to ensure that these key requirements are achieved in Vietnam. A more realistic strategy might be to aim for a limited version of the OER model. The steps towards OER require time and effort from all parties; changing people's philosophy from "closed" to "open" is the biggest challenge. Regarding technical issues, it seems that securing the creation, publishing, and distribution of OER entirely based on FOSS would be time-consuming and difficult to 
achieve, hence, educational resources published in open access and with an open licence only should be encouraged. Once stakeholders are familiar with OER and the "open" concept, universities can start implementing open source to ensure the sustainability (i.e., the long-term continuation) of their repositories.

Similar to that of other nations reported on by various scholars (e.g., McGreal, 2017; Ngimwa \& Wilson, 2012; Pena, 2009), Vietnam's lack of funding for initiating and sustaining a project is identified as an impediment to IOER development. As noted, most activities of public HEOs in Vietnam are under the direct management of the government and funded through the state budget. This explains why foreign and private universities are more active in the open movement in this country, as they are more flexible in mobilising their budgets. Given the potential that OER offer to education, the government and other authorised bodies in Vietnam should give greater autonomy to public HEOs, allowing them to have the freedom to formulate and execute operational strategy and plans for their institutions.

This investigation has explored many sociocultural challenges that constrain higher education providers in developing IOER. Among them, the lack of stakeholders' advocacy was identified as the biggest obstacle to the OER movement in Vietnam, also recognised in previous research in other countries (Hu et al., 2015; Thumbumrung \& Aroonpiboon, 2018; Torres, 2013). This challenge can be addressed if higher education communities can be convinced of the real benefits of OER. This study contends that providing opportunities to use high-quality OER from overseas contributes significantly to changing users' views about free and open resources. HEOs should facilitate the localisation of highquality OER into Vietnamese. Language is an enabling factor for developing IOER in Vietnam, as despite having 54 ethnic groups, Vietnamese is the single official language of the country. According to a 2018 UNESCO survey, the adult literacy rate in Vietnam was 95\%, which is considered an excellent advantage for localising OER in Vietnamese.

Important to IOER development is government and education administrators developing appropriate strategies and policies. Such policies should be aimed at tackling the financial, legal, and sociocultural issues identified. Although the official policy about OER has not been issued, the release by the government of Official Dispatch No. 4301/BGDĐT-GDTX in 2019, which outlines recommendations encouraging the creation and development of OER at HEOs, is a remarkable milestone and is expected to be a critical facilitator in boosting the OER movement in Vietnam (Ministry of Education and Training, 2019).

This research has investigated the influence of pedagogical issues on the development of IOER, in line with other studies (e.g., Hodgkinson-Williams, 2010; Thumbumrung \& Aroonpiboon, 2018; Torres, 2013). Despite the difficulties identified by the participants, positive moves have been made by higher education providers in Vietnam. For example, universities that have visionary top managers and proactive library staff (e.g., Thang Long University and Ha Long University) have recently taken steps to create and use OER (Do et al., 2019). Additionally, recognising the importance of libraries for teaching and learning, several universities (e.g., Ton Duc Thang University, Hai Phong Private University) have started to invest more in libraries, improving ICT infrastructure and recruiting skilled staff. These libraries have been empowered to organise, collaborate, and engage with other units within their universities to enhance the institution's academic reputation and education quality (Do et al., 2019). 
Further, a side effect of the COVID-19 worldwide pandemic has been to make online education mainstream. In early 2020, universities, institutions, and schools in many countries, including Vietnam, decided to move classes online to minimise the spread of COVID-19. More potential exists for OER in this environment, as educators can facilitate the rapid development of online courses, which could in turn lead to more interest in OER.

This research indicates that the limitations and inconsistencies of Vietnam's legal system are constraining IOER development in Vietnam. Other countries have reported similar problems (see, e.g., Hodgkinson-Williams, 2010; Hu et al., 2015; Pena, 2009). Nevertheless, the recent introduction of certain laws has opened the door for the OER movement to thrive in Vietnam. For instance, in June 2019, the Law on Education No. 43/2019/QH14 was approved by the National Assembly. Article 4, clause 3 of this law clearly states, "Developing an open education system, building a learning society to create opportunities for everyone to have access to education, learning at all levels, all forms, and lifelong"; and Article 6, clause 1 says, "The national education system is an open and interconnected education system including formal education and continuing education" (Vietnam Government Portal, 2019a). It is expected that the newly released Law on Libraries, which came into effect in July 2020, will help libraries to function more efficiently and boldly, as it clearly defines the rights, obligations, and responsibilities of agencies, organisations, and individuals with respect to libraries and their activities (Vietnam Government Portal, 2019b).

In general, this research contributes considerably to the knowledge of IOER development from the perspectives of higher education providers. As noted, the Vietnamese government has recently officially declared its support for the OER movement via official dispatches and documents. In responding, universities in Vietnam must actively create favourable conditions for their lecturers, researchers, students, and learners to harness and create OER. Universities can refer to this study's findings to develop strategic plans to leverage opportunities and overcome obstacles when developing IOER.

Although these findings resulted from investigation in Vietnam, they may be applicable in supporting the development of IOER in other countries that have similar economic, cultural, social, and/or educational conditions to Vietnam. In Vietnam, stakeholders' lack of awareness of OER and advocacy are the most frequently raised serious challenges. Although the exact nature of these challenges varies according to the context of specific countries, OER advocates in other countries might face similar issues. They are urged to organise more OER promotion and awareness-raising activities that increase recognition of OER and their advantages among stakeholders. Once stakeholders understand the potential of OER, they can recognise their need for OER use and decide to support the OER and IOER development. Decision-makers should also incorporate libraries and library staff in any OER-related projects. These activities can be accomplished with sound procedures and policy, especially those on recognition, commendation, and rewards on using and creating OER and developing IOER.

\section{Conclusion}

This research was designed to explore the opportunities in and challenges to the development of IOER in Vietnam. It identified challenges including: technological and infrastructure issues, economic constraints, sociocultural difficulties, pedagogical matters, and legal constraints. Many of these have not been previously noted in the literature. A number of opportunities were also identified, however, there remains a sense that they are outweighed by the challenges. This study also found that the 
opportunities and challenges of the OER movement in Vietnam are interconnected. It is beyond the scope of this study to examine the opportunities and challenges of using OER from the perspectives of users. A further study focusing on the viewpoints of users in using OER in Vietnam is therefore suggested.

\section{Acknowledgements}

The authors wish to express gratitude to Dr. Ross Harvey and Dr. Steven Wright from Monash University for their valuable feedback and editorial suggestions related to this article. 


\section{References}

Coughlan, T., Pitt, R., \& Farrow, R. (2019). Forms of innovation inspired by open educational resources: A post-project analysis. Open Learning: The Journal of Open, Distance and eLearning, 34(2), 156-175. https://doi.org/10.1080/02680513.2018.1552579

Do, M. (2013). Open educational resources in Vietnam. In G. Dhanarajan \& D. Porter (Eds.), Open education resources: An Asian perspective (pp. 161-174). COL and OER Asia. http://hdl.handle.net/11599/23

Do, V. H., Le, T. N., Nguyen, L., Nguyen, H. Q., Nguyen, T. K. D., Dong, D. H., Bui, T. T., Tran, D. H., \& Bui, T. A. T. (Eds.). (2019). Developing and harnessing open educational resources. Vietnam National University Publishing House. https://giaoducmo.avnuc.vn/hoi-thao/kyyeu-hoi-thao-xay-dung-va-khai-thac-tai-nguyen-giao-duc-mo-42.html

Dutta, I. (2016). Open educational resources (OER): Opportunities and challenges for Indian higher education. Turkish Online Journal of Distance Education, 17(2), 110-121. https://eric.ed.gov/?id=EJ109724.5

Elman, C., Gerring, J., \& Mahoney, J. (Eds.). (2020). The production of knowledge: Enhancing progress in social science. Cambridge University Press. https://doi.org/10.1017/9781108762519

European Commission. (2013). Opening up education: Innovative teaching and learning for all through new technologies and open educational resources. EUR-Lex. https://eurlex.europa.eu/legal-content/EN/TXT/PDF/?uri=CELEX:52013DC0654\&from=EN

Friesen, N. (2009). Open educational resources: New possibilities for change and sustainability. International Review of Research in Open and Distributed Learning, 1O(5). https://doi.org/10.19173/irrodl.v10i5.664

Glesne, C., \& Peshkin, A. (1992). Becoming qualitative researchers: An introduction. Longman.

Goldkuhl, G. (2012). Pragmatism vs. interpretivism in qualitative information systems research. European Journal of Information Systems, 21(2), 135-146. https://doi.org/10.1057/ejis.2011.54

Hodgkinson-Williams, C. (2010). Benefits and challenges of OER for higher education institutions. OAsis. http://oasis.col.org/handle/11599/3042

Hsieh, H. F., \& Shannon, S. E. (2005). Three approaches to qualitative content analysis. Qualitative Health Research, 15(9), 1277-1288. https://doi.org/10.1177/1049732305276687

Hu, E., Li, Y., Li, J., \& Huang, W. H. (2015). Open educational resources (OER) usage and barriers: A study from Zhejiang University, China. Educational Technology Research and Development, 63(6), 957-974. https://doi.org/10.1007/s11423-015-9398-1

Markoff, J. (2005). What the dormouse said: How the sixties counterculture shaped the personal computer industry. Viking. 
McGreal, R. (2017). Special report on the role of open educational resources in supporting the sustainable development goal 4: Quality education challenges and opportunities. The International Review of Research in Open and Distributed Learning, 18(7). https://doi.org/10.19173/irrodl.v18i7.3541

Ministry of Education and Training. (2019). Official dispatch no. 4301/BGDĐT-GDTX regarding the creation and development of OER. https://moet.gov.vn/giaoducquocdan/giao-duc-thuongxuyen/Pages/chi-tiet-van-ban-chi-dao-dieu-hanh.aspx?ItemID=2586

Mosharraf, M., \& Taghiyareh, F. (2016). The role of open educational resources in the eLearning movement. Knowledge Management \& E-Learning: An International Journal, 8(1), 10-21. https://doi.org/10.34105/j.kmel.2016.08.002

Mtebe, J. S., \& Raisamo, R. (2014). Challenges and instructors' intention to adopt and use open educational resources in higher education in Tanzania. International Review of Research in Open and Distributed Learning, 15(1), 249-271. https://doi.org/10.19173/irrodl.v15i1.1687

Ngimwa, P., \& Wilson, T. (2012). An empirical investigation of the emergent issues around OER adoption in Sub-Saharan Africa. Learning, Media and Technology, 37(4), 398-413. https://doi.org/10.1080/17439884.2012.685076

Organisation for Economic Co-operation and Development (OECD). (2007). Giving knowledge for free: The emergence of open educational resources. https://www.oecd.org/education/ceri/38654317.pdf

Pena, H. (2009). Higher education: The success and challenges in open education resources (OER). http://eprints.rclis.org/13743/1/pena.pdf

Stracke, C. M. (2019). Quality frameworks and learning design for open education. The International Review of Research in Open and Distributed Learning, 20(2), 180-203. https://doi.org/10.19173/irrodl.v20i2.4213

Stracke, C. M. (2020). Open science and radical solutions for diversity, equity and quality in research: A literature review of different research schools, philosophies and frameworks and their potential impact on science and education. In D. Burgos (Eds.), Radical solutions and open science. An open approach to boost Higher Education (pp. 17-37). https://doi.org/10.1007/978-981-15-4276-3 2

Stracke, C. M., Downes, S., Conole, G., Burgos, D., \& Nascimbeni, F. (2019). Are MOOCs open educational resources? A literature review on history, definitions and typologies of OER and MOOCs. Open Praxis, 11(4), 331-341. http://doi.org/10.5944/openpraxis.11.4.1010

Thumbumrung, T., \& Aroonpiboon, B. (2018). The emergence of Thai OER to support open education. In E. Méndez, F. Crestani, C. Ribeiro, G. David, \& J. Lopes (Eds.), Digital libraries for open knowledge (pp. 368-372). Springer. https://doi.org/10.1007/978-3-030-00066-0 42 
Torres, N. M. (2013). Embracing openness: The challenges of OER in Latin American education. Open Praxis, 5(1), 81-89. doi.org/10.5944/openpraxis.5.1.33" https://doi.org/10.5944/openpraxis.5.1.33

Truong, V. (2020, August 10-14). What factors affect the development of institutional open educational resource repositories? An empirical investigation [Paper presentation]. 2020 Americas Conference on Information Systems (AMCIS 2020), virtual. https://aisel.aisnet.org/amcis2020/is education/is education/19/

UNESCO. (2002). Open courseware and developing countries: Building a community. The William and Flora Hewlett Foundation. https://hewlett.org/wpcontent/uploads/2016/08/OpenCourseWareandDevelopingCountries.pdf

UNESCO. (2017). Second world OER congress Ljubljana OER action plan. https://en.unesco.org/sites/default/files/ljubljana oer action plan 2017.pdf

UNESCO. (2018). Vietnam education and literacy. http://uis.unesco.org/country/VN

UNESCO. (2019). Open educational resources (OER): Recommendation on OER. http://portal.unesco.org/en/ev.phpURL ID $=49556 \&$ URL DO=DO TOPIC\&URL SECTION=201.html

Vietnam Government Portal. (2019a). Law no. 43/2019/QH14 of the National Assembly: Law on education.

http://vanban.chinhphu.vn/portal/page/portal/chinhphu/hethongvanban?class id=1\& pag

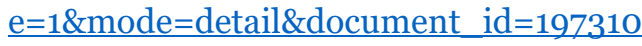

Vietnam Government Portal. (2019b). Law no. 46/2019/QH14 of the National Assembly: Law on libraries.

http://vanban.chinhphu.vn/portal/page/portal/chinhphu/hethongvanban?class id=1\& pag $\underline{\mathrm{e}=1 \& \text { mode }=\text { detail } \& \text { document } \mathrm{id}=198547}$

Williamson, K. (2017). Populations and samples. In K. Williamson \& G. Johanson, (Eds.), Research methods: Information, systems, and contexts (2nd ed., pp. 359-377). Chandos Publishing. https://www.elsevier.com/books/research-methods/williamson/978-0-08-102220-7

\section{Athabasca}

University

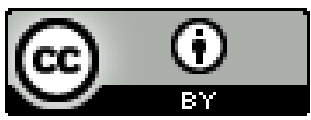

